\title{
THE FACTORS INFLUENCING ECONOMIC GROWTH IN INDONESIA
}

\author{
Dian Citra Amelia ${ }^{1 *}$, Sri Fajar Ayu ${ }^{2}$ \\ ${ }^{1 *}$ Departmen of Economics, Postgraduate Program Universitas Negeri Medan \\ ${ }^{2}$ Faculty of Economics and Business Universitas Sumatera Utara \\ Email: yourenewae@yahoo.com
}

\begin{abstract}
This research is based on the fact that the state of economic growth in Indonesia tends to fluctuate, even more often decrease. This is because the government policy is not appropriate to improve the economic growth of Indonesia. This study aims to determine and analyze the factors of foreign direct investment, inflation, international trade, and government expenditure that affect economic growth in Indonesia. The problem in this research is due to the limited fund in economic development both structure and infrastructure so that economic growth tends to decrease. Therefore, appropriate strategies must be taken to overcome the limitations in promoting economic growth. From this problem, this research aims to see how big influence of foreign direct investment (FDI), inflation (INF), international trade (NX) and government expenditure (GE) variable to economic growth. The data used in this study is secondary data (periodical data) in the period of observation 1996-2014 obtained from the World Bank and Statistics of Indonesia. To identify the influence of the variables used in this study used the VAR (Vector Autoregression) method. The results of this study show that equation regression shows that FDI (-1) has a negative influence on economic growth and FDI (-2) has a positive effect on economic growth, INF (-1) and INF (-2) have positive effects on economic growth, Variable NX (-1) has a positive effect on economic growth but NX (-2) has a negative effect on economic growth, and GE variable (-1) has a positive effect on economic growth while GE (-2) has a negative effect on growth Economy.
\end{abstract}

Key words: Economic Growth, Foreign direct investment, Inflation, International Trade, Government Expenditure.

\section{INTRODUCTION}

7 conomic growth is one of the main elements in economic development and it has broad policy implications, although it is realized that the development process is not only determined by economic factors such as: natural resources, capital accumulation, organization, technological progress, division of labor and scale of production but also non-economic factors such as: social factors, human factors, political and administrative factors. Economic growth is an indicator to assess the success of a country from economic activities that can encourage an increase in output and can also increase the prosperity and welfare of the community.

Economic growth problems can be viewed as macroeconomic problems in the long run. From one period to another the ability of a country to produce goods and services will

$$
\text { QE Journal | Vol.08 - No.01 - } 34
$$


increase. This increased capability is due to the production factors that will always increase in number and quantity. Investments will increase the amount of capital goods. The technology used is developing. Besides, manpower and education add skills. Economic growth is very much influenced by several factors, but in this research the factors used to influence economic growth are inflation, foreign direct investment, international trade and government spending. Inflation can be used as an indicator that shows economic instability for a country. Inflation stability is a prerequisite for sustainable economic growth and ultimately provides benefits for the improvement of people's welfare. Then foreign direct investment, which aims to facilitate production and infrastructure activities for developing countries in particular. Foreign direct investment is also needed to accelerate the economy because this can help the industrialization process in order to create wider employment opportunities. Then trade liberalization in net exports, export and import is needed in developing an economy and has an important role as a driver of the national economy. And finally government spending, government spending is also one of the main factors determining the rate of economic growth. Government expenditure is measured from the total routine expenditure and government development expenditure. Government spending that is too small will harm economic growth, proportional government spending will increase economic growth and wasteful government spending will hamper economic growth. But in general government spending has a positive impact on economic growth.

According to Harrord-Domar, to spur economic growth, new investment is needed which is a net addition to reserves or capital stock (Todaro, 2006: 129). Apart from investment, Indonesia's economic growth is also supported by the international trade sector, namely exports and imports. The economic turmoil that occurred in Indonesia, both external and internal, also affected economic variables. In 2001, there was an increase in inflation as a result of the government's policy to raise the price of fuel oil in mid-June 2001 which was followed by an increase in the basic electricity tariff and an increase in telephone pulses. The rate of inflation in Indonesia decreased in 2003 due to the return to normalcy of supply of goods and improvement in distribution channels of goods. In addition, the government's decision to postpone the increase in electricity and telephone rates in the last quarter of 2003 also contributed to the low inflation rate. In 2004 there was an increase in inflation compared to the previous year, with different factors quite dominant in influencing inflation, among others, factors increasing the price of foodstuffs and external factors, particularly the rupiah exchange rate. The increase in fuel prices in October 2005 immediately reduced people's purchasing power and increased the rate of inflation which then resulted in a decrease in production value. The increase in fuel prices and the tightening of world monetary impacts on the exchange rate depreciation, which in turn slows down investment growth.

Audrey and Evan (2007) show that exports, investment and inflation have an influence on the economic growth of Indonesia, Malaysia and Thailand, only the difference is that the effect is positive or negative. Exports have a positive effect on the economic growth of Indonesia, Malaysia and Thailand. Inflation has a negative effect on economic growth in Thailand and Malaysia but has a positive effect on economic growth in Indonesia. The 
inflation rate in Indonesia has been quite stable for several years, which brings a positive relationship between inflation and economic growth. Investment has a positive effect on economic growth in Indonesia, Malaysia and Thailand. Erwin Mardalena (2009) states that based on the results of the regression model estimation, the international trade variable (export-import) has a positive and significant effect on economic growth, while the private investment variable has a positive but insignificant effect on economic growth. Dewi et al (2013) stated that consumption, investment, government spending and net exports have a significant and positive effect on economic growth in Indonesia. Ahmad and Latri (2008) show that the coefficient of real government spending is positive and significant. This means that government spending has an important role in increasing economic growth in Indonesia. Meanwhile, Sjoberg (2003) in Sweden shows that too much government spending will hinder economic growth. The same study was conducted by Sinha (2000) in Malaysia which examined the relationship between government spending and economic growth. Sinha found the results were not significant.

\section{REVIEW OF LITERATURE}

\section{Foreign Direct Investment (FDI)}

Foreign direct investment (FDI) as a component of capital flows into a region is considered a relatively stable capital flow and has a small risk compared to other capital flows, for example portfolio investment and foreign debt. Foreign direct investment has more advantages including permanent (long-term) nature, contributing to and transfer of technology, transfer of management skills and creating new jobs. foreign direct investment helps reduce the shortfall of domestic saving through additional capital thereby increasing the marginal saving rate and the rate of capital formation. In addition, the use of foreign capital does not only address capital shortages but also technological backwardness. Along with cash and physical capital, foreign capital also brings with it technical skills, expertise, organizational experience, market information, advanced production techniques, product renewal, and so on. It also trains the local workforce in new skills. All of this accelerates economic development. Thus, development financing originating from foreign investment is very important for economic development. Investment which is allocated to development projects means that it will increase capital, which in turn, the additional capital will result in an increase in the standard of living of the community, where one of the indicators is economic growth.

(Cuza: 2012) The purpose of this study is to emphasize the importance of the flow of foreign direct investment for the targeted country's economic growth, through theoretical research and empirical data. The results of this study prove that the impact of foreign direct investment in the recipient countries of capital, the results obtained are as follows that the impact of foreign capital flows has succeeded in stimulating economic growth and is able to stimulate financial markets, absorption of domestic labor, advancing human capital and technology. 


\section{Inflation}

Boediono (2008: 155) says that inflation is the process of increasing general prices of goods continuously. Meanwhile, Sukirno (2008: 14) defines inflation as the process of increasing prices prevailing in an economy. In general, inflation can be interpreted as an increase in the price level of goods and services in general and continuously as well as a decrease in people's purchasing power. According to Miskhin (2009), inflation is defined as a continuous and rapid increase in the price level. Putong (2013) states that inflation is a process of increasing general prices continuously which results in a decrease in people's purchasing power because in real terms their income level also decreases. Inflation generally has an unfavorable impact on the economy, the high rate of inflation that occurs in a country. Based on the definition of inflation above, it can be concluded that inflation is a tendency to increase the price of goods in general and occurs continuously.

(Gokal: 2004) In this study, researchers have analyzed several different economic theories to ensure the relationship between inflation and economic growth, which emphasizes the need for incentives to save and invest if the nation's economy is growing. Keynesian theory provides the AD-US framework, a more comprehensive model for linking inflation to economic growth. Monetaryism again emphasizes the important role of monetary growth in determining inflation, while neoclassical and economic growth theory through investment and capital accumulation. This study also examines recent empirical literature. This research includes research conducted by Sarel (1996), Andres \& Hernando (1997) and Ghosh \& Phillips (1998) and Khan \& Senhadji (2000). The results of this study prove a positive correlation exists between inflation and growth.

\section{International Trade}

Muhammad Sood (1995) argues that international trade is one of the activities in the economic sector which has a strategic role in efforts to accelerate economic growth and equity and make a meaningful contribution to creating business fields and expanding job opportunities and increasing income. Free market theory helps explain the direction and composition of trade between several countries and how it affects the structure of a country's economy. In addition, international trade theory can also show that there are benefits arising from international trade (Nopirin, 1991).

(Behname: 2012) in this study, researchers again obtain empirical evidence about the relationship between trade openness and long-term economic growth during the sample period 1960-2000. It allows us to better understand the stance of trade policy and the long-term dynamics of economic growth. Researchers carry out empirical investigations using various measures of disclosure of several variables. Research shows that open trade is positively and significantly correlated with long-term economic growth. 


\section{Government Expenditure}

Government spending reflects government policy. If the government has established a policy to purchase goods and services, government spending reflects the costs that must be incurred by the government to implement the policy. The theory of government spending can also be grouped into 2 parts, namely macro theory and micro theory. Government spending as an important instrument of fiscal policy is expected to be able to stimulate economic activity and increase economic growth. The government optimizes this role by increasing government spending on Gross Domestic Product (GDP). In real terms, government spending has also increased in line with the increase in Gross Domestic Product (GDP). The role of the government in the economy is indicated by spending on the economy as a percentage of total expenditure, which tends to increase.

The amount of government spending that has a positive influence on economic growth has a certain limit. Government spending will support economic growth if the government is able to create conditions in which the large share of government spending on the entire output level can be used to provide public goods that are used as competitive production inputs.

Wagner raises a general hypothesis regarding a positive long-run relationship between government spending and economic development based on observations in European countries, U.S. and Japan. The hypothesis explains that economic growth is a fundamental factor that determines the growth of the public sector, including government spending and consumption. This statement is called the law of expending state activity or Wagner's Law.

\section{Economic Growth}

Economic growth is one of the benchmarks for assessing the economic development of a country. According to Murni (2006: 173), economic growth is a condition of potential GNP development which reflects the growth in output per capita and the increasing standard of living of the people. According to Sukirno (2008: 423), economic growth means the physical development of the production of goods and services prevailing in a country. Meanwhile, according to Samuelson and Nordhaus (2004: 249) economic growth is a picture of the potential GDP expansion or national output of the State. So it can be concluded that economic growth is a process of increasing the national income of a country within a certain time or period.

Economic growth is a significant increase in national income (with an increase in per capita income) in a certain calculation period. According to Schumpeter (Putong, 2013), economic growth is an increase in output (national income) which is caused by a natural increase in the rate of population growth and the rate of saving. Meanwhile, according to some development economists, economic growth is a term for a developed country to describe the success of its development, meanwhile for developing countries the term economic development is used (Putong, 2013). According to Mankiw (2003), economic growth is seen from the total aggregate expenditure. GDP $(\mathrm{Y})$ is divided into 
four components: consumption (C), investment (I), government spending (G), and net exports (NX): $Y=C+G+N X$. GDP is divided into two, namely Real GDP and Nominal GDP. Real GDP which assesses the production of goods and services at fixed prices.

In his analysis, Kuznets (Todaro, 2003) suggests six characteristics or characteristics of the economic growth process found in almost all countries as follows:

1. High rate of growth in output per capita and population growth.

2. A high rate of increase in total factor productivity (TFT), namely, the output produced by each unit of input from all the inputs or production factors used to make said output.

3. A high degree of economic structural transformation.

4. High levels of social and ideological transformation.

5. There is a tendency for countries that have started or with developed economies to try to penetrate other parts of the world as new marketing areas and sources of raw materials.

6. Limited spread of economic growth which only reaches about one third of the world's population.

The standard of living for most families in many countries has improved over time. This is indicated by the existence of economic growth in the world, which we can see by analyzing the Growth Domestic Product (GDP) data.

\section{RESEARCH METHOD}

To identify the influence of the variables used in this study, the VAR (Vector Autoregression) method was used. The VAR (Vector Autoregression) model is used to explain the dynamic behavior between observed variables that are interrelated. The use of VAR is expected to eliminate the simultaneity problem between two endogenous variables. This research method will describe the impulse response and variance decomposition functions, which are the properties of the VAR model to see the shocks of the innovation variable against other variables through the development of the VAR structure.

This study will observe endogenous variables, namely Economic Growth (EG), Foreign Direct Investment (FDI), Inflation (INF), International Trade (NX), Government Expenditure (GE) in Indonesia, so the interdependent relationship between the five variables is specified into a system of equations. which consists of the following five equations:

$$
\begin{aligned}
& \mathrm{EG}_{\mathrm{t}}= \alpha_{1}+\sum_{j=1}^{k} 1 \mathrm{jEG}_{t-j}+\sum_{j=1}^{k} 1 \mathrm{jFDI}_{t-j}+\sum_{j=1}^{k} 1 \mathrm{jNF}_{t-j}+\sum_{j=1}^{k} 1 \mathrm{jNX}_{t-j}+ \\
& \sum_{j=1}^{k} 1 \mathrm{jGE}_{t-j}+\varepsilon_{1} \\
& \mathrm{FDI}_{\mathrm{t}}= \alpha_{2}+\sum_{j=1}^{k} 2 \mathrm{jFDI}_{t-j}+\sum_{j=1}^{k} 2 \mathrm{jINF}_{t-j}+\sum_{j=1}^{k} 2 \mathrm{jNX}_{t-j}+\sum_{j=1}^{k} 2 \mathrm{jGE}_{t-j}+ \\
& \sum_{j=1}^{k} 2 \mathrm{jPDB}_{t-j}+\varepsilon_{2} \\
& \mathrm{INF}_{\mathrm{t}}=\alpha_{3}+\sum_{j=1}^{k} 3 \mathrm{jINF}_{t-j}+\sum_{j=1}^{k} 3 \mathrm{jNX}_{t-j}+\sum_{j=1}^{k} 3 \mathrm{jGE}_{t-j}+\sum_{j=1}^{k} 3 \mathrm{jEG}_{t-j}+ \\
& \quad \sum_{j=1}^{k} 3 \mathrm{jFDI}_{t-j}+\varepsilon_{3}
\end{aligned}
$$




$$
\begin{aligned}
& \mathrm{NX}_{\mathrm{t}}=\alpha_{4}+\sum_{j=1}^{k} 4 \mathrm{jNX}_{t-j}+\sum_{j=1}^{k} 4 \mathrm{jGE}_{t-j}+\sum_{j=1}^{k} 4 \mathrm{jEG}_{t-j}+\sum_{j=1}^{k} 4 \mathrm{jFDI}_{t-j}+ \\
& \sum_{j=1}^{k} 4 \mathrm{JNF}_{t-j}+\varepsilon_{4} \\
& \mathrm{GE}_{\mathrm{t}}=\quad \alpha_{5}+\sum_{j=1}^{k} 5 \mathrm{jGE}_{t-j}+\sum_{j=1}^{k} 5 \mathrm{jEG}_{t-j}+\sum_{j=1}^{k} 5 \mathrm{jFDI}_{t-j}+\quad \sum_{j=1}^{k} 5 \mathrm{jINF}_{t-j}+ \\
& \sum_{j=1}^{k} 5 \mathrm{jNX} \mathrm{X}_{t-j}+\varepsilon_{5}
\end{aligned}
$$

In this research, the testing stages include (1) Init Root Test. (2) Optimal Lag Test and (3) Cointegration Test. The impact of the shock of an innovation variable on other variables is traced through the impulse response and Variance Decomposition functions.

\section{RESULT AND DISCUSSION}

The crisis that hit Indonesia since mid-1997 has gradually subsided and towards the end of the 1998/99 reporting year, it has begun to show signs of improvement. The development of various key economic indicators shows that the economic performance has begun to pass past rock bottom. The Gross Domestic Product (GDP), which during 1998 experienced a very deep contraction, in the first quarter of 1999 showed an increase for the first time in the last four quarters although on an annual basis it still recorded a contraction.

Entering the beginning of 2000, the Indonesian economy was marked by a high level of optimism. Early signs of the economic recovery process began to appear since the third quarter of 1999. Monetary stability was also under control, as reflected in the achievement of a low inflation rate and a strengthening exchange rate until the end of 1999. The socio-political and security conditions at that time were already under control. improving, with the process of implementing the national leadership election which is considered to be running smoothly and democratically. These encouraging developments have allowed further cuts in interest rates to the end of 1999 and stimulated the capital market so that the economic recovery process regained momentum. In general, the condition of the Indonesian economy up to now has shown positive developments, marked by increasingly stable macroeconomic conditions. Consistent monetary and fiscal policies supported by several progress made in economic restructuring have helped to achieve economic and monetary stability during the reporting year.

Consumption has experienced relatively stable growth, while investment activity has increased sharply, after experiencing low growth in the last three years. Likewise, the growth in exports of goods and services continues to increase, in line with the increase in world trade volume followed by soaring prices for oil and gas (oil and gas) and non-oil and gas commodities. Meanwhile, the increase in investment activity was driven by improving domestic demand and financial support. In line with the increasing domestic and export demand, import activities of goods and services also experienced a high increase. This development has succeeded in improving the level of community welfare, which is reflected in an increase in per capita income and a decrease in the level of poverty. This high economic growth was supported and met with maintained 
macroeconomic stability. Amid the ongoing adjustment to global economic imbalances and the decline in people's purchasing power following the October 2005 increase in fuel oil prices, Indonesia's economy in $\mathbf{2 0 0 6}$ has gradually improved.

Economic growth in Indonesia is seen from the value of GDP based on constant prices. The following is the development of GDP in 1996-2014.

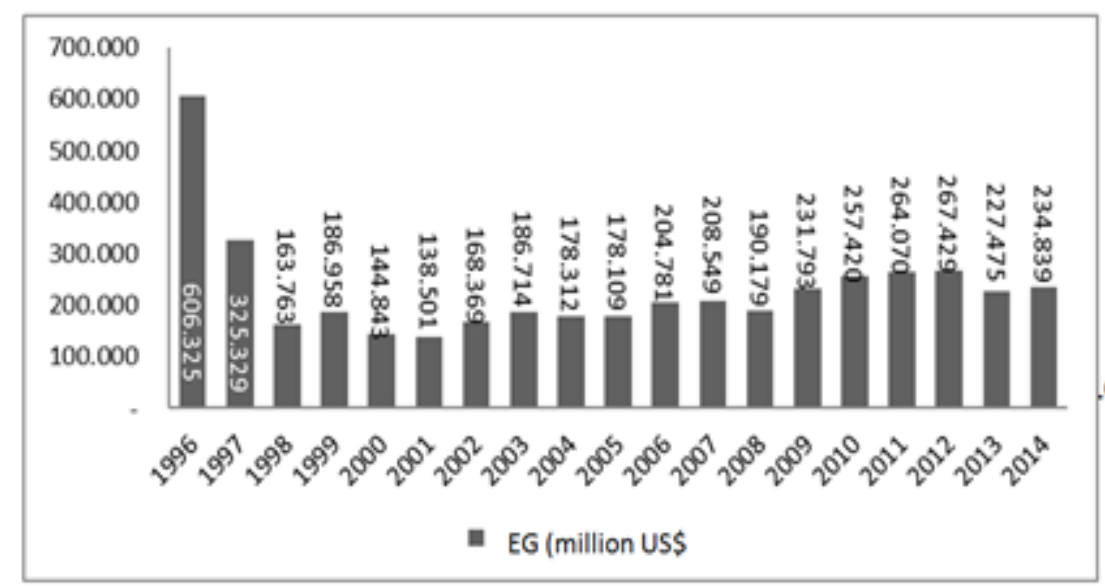

Figure 1: Economic Growth Development 1996-2014 (Million US\$)

The results of the data stationarity test for all the variables studied are as follows:

Table 1: Stationary Test Results

\begin{tabular}{|l|l|l|l|l|l|l|}
\hline Variable & $\begin{array}{c}\text { ADF-test } \\
\text { Level }\end{array}$ & $\begin{array}{c}\text { ADF-test } \\
1 \text { st } \\
\text { difference }\end{array}$ & $\begin{array}{c}\text { ADF-test } \\
\text { 2nd } \\
\text { difference }\end{array}$ & $\begin{array}{c}\text { Critical- } \\
\text { test 1\% }\end{array}$ & $\begin{array}{c}\text { Critical- } \\
\text { test 5\% }\end{array}$ & Critical-test 10\% \\
\hline EG & -1.940646 & -8.337673 & - & -3.959148 & -3.081002 & -2.681330 \\
\hline FDI & 0.158071 & -4.791066 & - & -3.040391 & -3.040391 & -2.660551 \\
\hline INF & -8.617175 & - & - & -3.065585 & -3.065585 & -2.673459 \\
\hline NX & -1.011009 & -4.563607 & - & -2.699769 & -1.961409 & -1.606610 \\
\hline GE & -5.221822 & - & - & -3.857386 & -3.040391 & -2.660551 \\
\hline
\end{tabular}

Source: Eviews 6.0 Unit Root test Results

From the Augmented Dikey Fuller results in Table 1 above, it can be seen that there are stationary data at level 1 (0), namely INF and GE, while for GDP, FDI and NX the ADF-test is carried out at the first difference level, then the data is stationary. Where the ADFtest value is greater than the critical value at various levels of confidence $(1 \%, 5 \%, 10 \%)$.

Testing the optimal lag length is very useful for eliminating the problem of autocorrelation (the correlation between period $t$ interferers and time-ordered $t-1$ errors) in the VAR system. So that with the optimal lag test it is expected that the autocorrelation problem will not arise again. Based on this study using the SC criteria, the lag time is 2 .

The cointegration test in variables using the VAR model makes it possible to evaluate the equilibrium relationship in the long run. From the results of the cointegration test carried out, it can be seen that the calculated Trace Statistic and maximum Eigenvalue are greater than the critical value, so there is cointegration at the $5 \%$ level. And the Trace 
Statistic and maximum eigenvalue values are greater than the critical value, which means that there is a long-term relationship between the proven variables.

VAR estimation is supported by the use of Lag, the selection of the Lag used is determined by the optimal lag. VAR stability is seen from the inverse roots value of the AR polynomial characteristics. Based on Table 4.9. The modulus value of all unit roots based on the VAR estimation stability test has a modulus of less than 1 (one), so that the VAR estimation fulfills the stable condition using Lag.

Table 2: Modulus Values of All Unit Roots

Roots of Characteristic Polynomial

Endogenous variables: $D(P D B) D(F D I) D(I N F) D(N X) D(G E)$

Exogenous variables: $\mathrm{C}$

Lag specification: 12

Date: 01/22/17 Time: 11:37

\begin{tabular}{ll}
\hline \hline Root & Modulus \\
\hline \hline $0.121552-0.870927 i$ & 0.879368 \\
$0.121552+0.870927 i$ & 0.879368 \\
-0.705324 & 0.705324 \\
$-0.152023-0.623917 i$ & 0.642171 \\
$-0.152023+0.623917 i$ & 0.642171 \\
$-0.565319-0.132845 i$ & 0.580718 \\
$-0.565319+0.132845 i$ & 0.580718 \\
$0.270888-0.482604 i$ & 0.553432 \\
$0.270888+0.482604 i$ & 0.553432 \\
0.411143 & 0.411143 \\
\hline \hline
\end{tabular}

No root lies outside the unit circle.

VAR satisfies the stability condition.

Source: Results of the Modulus of All Root Unit Eviews 6.0

The choice of lag used is also determined by the optimal lag, carried out on the VAR model testing to see the maximum lag length of the stable VAR system. The VAR system is said to be stable (stationary) if all unit roots have a modulus less than one and all of them are located in the unit circle. If the VAR system is unstable then some results (such as standard error in impulse response) will be invalid. Based on the image of the inverse roots of ar characterristic polynominal, it can be seen that the model specification is stable.

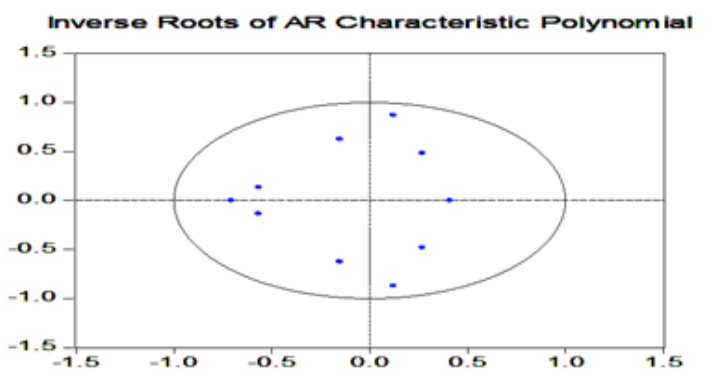

Figure 2: Modulus Values across Unit Roots 
The results of research with Lag 2 for 1996-2014 data, the VAR model for Economic Growth (EG), Foreign Direct Investment (FDI), Inflation (INF), International Trade (NX), Government Expenditure (GE) are in accordance with the research VAR model equation , each of which is:

$E G=4751.554+0.531363$ PDB $(-1)-0.288593$ PDB $(-2)+1.180289$ FDI $(-1)+0.0083594$ FDI(-2) + 1389.920 INF(-1) - 1335.155 INF(-2) + 0.124794 NX(-1) - 0.416843 NX(-2) + $0.542262 \mathrm{GE}(-1)+0.145666 \mathrm{GE}(-2)$

The largest and most positive contribution to GDP was INF (-1) of 1389,920 . Followed by FDI $(-1)$ of 1,180289 . meanwhile, FDI $(-2)$ has less influence and has the smallest contribution to GDP of 0.083594 .

In innovation accounting, the variables tested were variance decompotion and response impulses. This is done to analyze the relationship or correlation between each variable. Impulse response analysis provides a practical vision for interpreting how time series behaves in response to various shocks in a system of VAR equations. Since all variables are endogenous in the VAR model, every shock in one equation is transmitted throughout the system, so an impulse analysis of the response of one variable to another variable in a system involves another set of variables as well. The impulse response function of all variables for all types of shocks is evaluated by the Cholesky impulse decomposition method in this case the order is EG, FDI, INF, NX, GE.
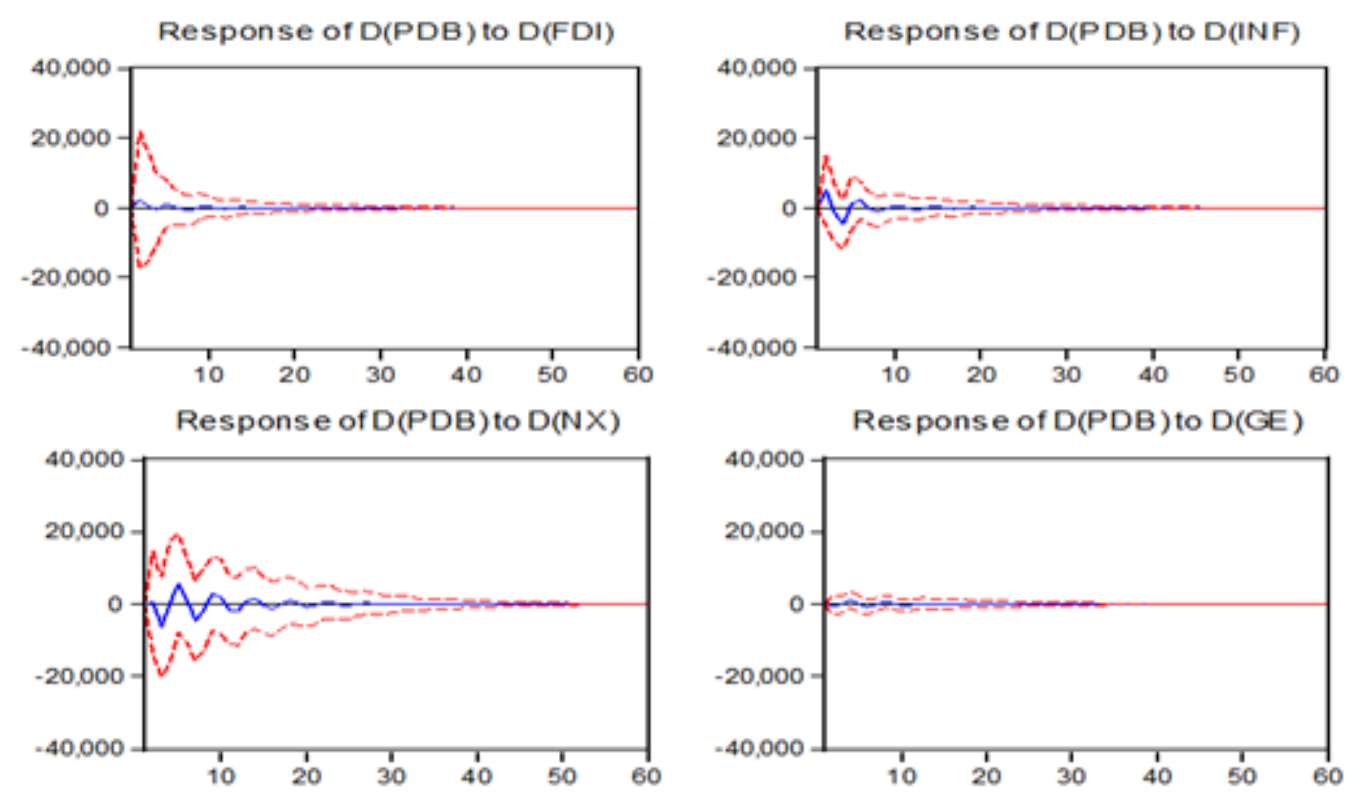

Figure 3: Impulse Response Function

The picture above shows the Impulse Response Function of the FDI, INF, NX and GE variables on economic growth. In the Response of $D(E G)$ to FDI and Response of $D$ (EG) to $\mathrm{GE}$, it can be seen that the shock in FDI provides a positive and non-permanent response to economic growth. In the Response of $D(E G)$ to INF, the shock in INF gives a positive and impermanent response to economic growth, although in the following period it tends to fluctuate. In the Response of $D(E G)$ to NX, a shock in net exports gives 
a positive and non-permanent response to economic growth. The period after that tends to fluctuate. Briefly, the IRF explanation can be seen in the following table.

Table 3: Response of $D(E G)$

\begin{tabular}{|c|c|c|c|c|c|}
\hline \multicolumn{6}{|c|}{ Response of $\mathrm{D}(\mathrm{PDB})$ : } \\
\hline Period & $\mathrm{D}(\mathrm{PDB})$ & $\mathrm{D}(\mathrm{FDI})$ & $\mathrm{D}(\mathrm{INF})$ & $D(N X)$ & $\mathrm{D}(\mathrm{GE})$ \\
\hline \multirow[t]{2}{*}{1} & 25444.49 & 0.000000 & 0.000000 & 0.000000 & 0.000000 \\
\hline & (4497.99) & $(0.00000)$ & $(0.00000)$ & $(0.00000)$ & $(0.00000)$ \\
\hline \multirow[t]{2}{*}{2} & 2944.167 & 2331.519 & 4915.734 & 492.9525 & -443.8700 \\
\hline & (9787.66) & (9814.22) & $(5001.41)$ & (7045.37) & (1274.14) \\
\hline \multirow[t]{2}{*}{3} & -2223.924 & 498.8478 & -1479.593 & -6341.775 & -66.38755 \\
\hline & (11963.0) & (7902.35) & (4073.91) & (6912.79) & (1153.69) \\
\hline 4 & -225.4125 & -539.0874 & -4733.670 & 458.4156 & 1193.404 \\
\hline \multirow[t]{2}{*}{21} & -249.2372 & -90.03364 & -151.0713 & -434.1919 & 94.49755 \\
\hline & $(1065.28)$ & (486.598) & (736.953) & $(2625.71)$ & (404.664) \\
\hline \multirow[t]{2}{*}{22} & -162.8048 & 15.05978 & -100.6172 & 445.8586 & 65.84769 \\
\hline & (961.070) & (393.345) & $(679.436)$ & $(2349.41)$ & (387.281) \\
\hline \multirow[t]{2}{*}{23} & 151.6491 & 76.22283 & 93.21561 & 443.8542 & -57.40990 \\
\hline & $(905.880)$ & (403.490) & (608.966) & $(2245.63)$ & (338.925) \\
\hline 24 & 164.4966 & 4.694114 & 99.24916 & -236.9605 & -64.63845 \\
\hline \multirow[t]{2}{*}{41} & 22.02499 & 5.679882 & 13.32197 & 15.16794 & -8.466742 \\
\hline & (159.918) & (59.9969) & (107.450) & (392.078) & (63.9921) \\
\hline \multirow[t]{2}{*}{58} & 1.422029 & 0.832742 & 0.856595 & 5.404668 & -0.527088 \\
\hline & (25.6139) & (9.56400) & (16.1589) & (64.9736) & (9.85825) \\
\hline \multirow[t]{2}{*}{59} & 1.983946 & 0.163063 & 1.202425 & -1.940824 & -0.777186 \\
\hline & $(22.8601)$ & $(7.67580)$ & $(15.0564)$ & $(55.8092)$ & (9.25278) \\
\hline \multirow[t]{2}{*}{60} & -0.617330 & -0.604316 & -0.370084 & -4.651187 & 0.218655 \\
\hline & $(20.3373)$ & (7.50550) & $(12.7463)$ & $(52.2968)$ & (7.82553) \\
\hline
\end{tabular}

The table above shows the Impulse Response Function D (EG) to FDI, INF, NX, and GE. In the Impulse Response Function D (EG) to EG, it can be seen that in the short term the first and second periods, the shock shows a positive response of 25444.49 and 2944,167. In the third and fourth periods, the shocks showed negative responses of $-2223,924$ and $-225,4125$. In the medium term, the twenty-first and twenty-second periods show a negative response of -249.2372 and -162.8048 . In the twenty-third and twenty-fourth periods, the shocks gave a positive response of 151.6491 and 164.4966. and long term in the fourty-first period, it can be seen that the shock gives a positive response of 22.02499. in the fifty-eighth and fifty-nineth periods, there was a shock giving a positive response of 1.422029 and 1.983946 . In the sixtieth period, it can be seen that the shock gave a negative response of -0.617330 .

Impulse Response Function D (EG) to FDI can be seen in the short term 1, it can be seen that the shock in FDI does not show any response. In the second and third periods, it was seen that there was a shock giving a positive response, namely 2331,519 and 498,8478 . In the fourth period, it is seen that there is a shock giving a negative response, which is equal to -539.0874 . In the medium term, the twenty-first period shows a negative response of -90.03364 . period 22 to 24 shows a shock giving a positive response of $15.05978,76.22283$ and 4.694114 . The long term shows that in the fourty-first period, 
there is a shock that gives a positive response of 5.679882. In the fifty-eighth and fiftynineth periods, there was a shock that gave a positive response of 0.832742 and $0 . .163063$. In the sixtieth period, it can be seen that the shock gave a negative response of -0.604316 .

Impulse Response Function D (EG) to INF can be seen in the short term 1, it can be seen that the shock in INF does not show any response. In the second period, it can be seen that the shock gave a positive response of 492.9525. In the third and fourth periods, it can be seen that the shock gave a negative response of $-1479,593$ and $-4733,670$. In the medium term, in the twenty-first and twenty-second periods, it can be seen that the shock gives a negative response of -151.0713 and -100.6172 . In the twenty-third and twenty-fourth periods, it can be seen that the shock gave a positive response of 93.21561 and 99.24916. Long term in the 41st period, it can be seen that the shock gave a positive response of 13.32197 . in the 58th and 59th periods, it can be seen that the shock gave a positive response of 0.856595 and 1.202425 . in the sixtieth period, it can be seen that the shock gives a negative response of -0.370084 .

Impulse Response Function D (PDB) to NX can be seen in the short run period 1, it can be seen that the shock on NX does not show any response. In the second period, it can be seen that the shock gave a positive response of 492.9525. In the third period, it can be seen that the shock gives a negative response of $-6341,775$. In the fourth period, it can be seen that the shock gave a positive response of 458.4156. In the medium term, the twenty-first period shows that the shock gives a negative response of -4341919 . In the twenty-second and twenty-third periods, it can be seen that the shock gave a positive response of 445.8586 and 443.8542 . In the twenty-fourth period, it can be seen that the shock gives a negative response of $-236,9605$. Long term in the fourty-first period, it can be seen that the shock gives a positive response of 15,16794 . in the fiftyeighth period, it can be seen that the shock gave a positive response of 5.404668. in the fifty-nineth and sixtieth periods, it can be seen that the shock gives a negative response of -1.940824 and -4.651187 .

Impulse Response Function D (EG) to GE is seen in the short term in the first period, it can be seen that the GE shock does not show any response. In the second and third periods, it can be seen that the shock gives a negative response of -443.8700 and 66.38755. In the fourth period, it can be seen that the shock gave a positive response of 1193,404 . Medium term In the twenty-first and twenty-second periods, it can be seen that the shock gives a positive response of 94.49755 and 65.84769 . In the twenty-third and twenty-fourth periods, it can be seen that the shock gave a negative response of 57.40990 and -64.63845 . Long-term in the fourty-first period, it can be seen that there is a shock giving a negative response of -8.466742 . in the the fifty-eighth and fifty-nineth periods, it can be seen that the shock gives a negative response of -0.527088 and 0.777186 . in the 60th period, it can be seen that the shock gave a positive response of 0.218655 . Variance decomposition aims to measure the estimated error variance of a variable. that is, how big is the difference before and after shocks, both from the variable itself and other variables. 
Table4: Variance Decomposition PDB

\begin{tabular}{|c|c|c|c|c|c|c|}
\hline Period & S.E. & $\mathrm{D}(\mathrm{PDB})$ & $\mathrm{D}(\mathrm{FDI})$ & $\mathrm{D}(\mathrm{INF})$ & $D(N X)$ & $D(G E)$ \\
\hline 1 & 25444.49 & 100.0000 & 0.000000 & 0.000000 & 0.000000 & 0.000000 \\
\hline 2 & 26194.09 & 95.62176 & 0.792266 & 3.521842 & 0.035416 & 0.028715 \\
\hline 3 & 27087.58 & 90.09168 & 0.774778 & 3.591700 & 5.514389 & 0.027452 \\
\hline 4 & 27533.99 & 87.20077 & 0.788192 & 6.431863 & 5.364749 & 0.214430 \\
\hline 21 & 29386.56 & 77.34508 & 0.997369 & 6.746630 & 14.52493 & 0.385994 \\
\hline 22 & 29390.65 & 77.32666 & 0.997118 & 6.745928 & 14.54391 & 0.386389 \\
\hline 23 & 29394.69 & 77.30804 & 0.997516 & 6.745077 & 14.56270 & 0.386664 \\
\hline 24 & 29396.35 & 77.30247 & 0.997406 & 6.745457 & 14.56756 & 0.387104 \\
\hline 41 & 29405.50 & 77.26156 & 0.997739 & 6.743905 & 14.60886 & 0.387938 \\
\hline 58 & 29405.62 & 77.26104 & 0.997741 & 6.743883 & 14.60939 & 0.387948 \\
\hline 59 & 29405.62 & 77.26104 & 0.997741 & 6.743884 & 14.60939 & 0.387948 \\
\hline 60 & 29405.62 & 77.26104 & 0.997741 & 6.743883 & 14.60939 & 0.387948 \\
\hline
\end{tabular}

Source: data processing with eviews 6

Based on the results of the research shown in Table 4, the results show that GDP in the first period, the estimated error variance of $100 \%$ is explained by GDP itself, while other variables, namely FDI, INF, NX, and GE do not respond at all, where the response is these variables appear in periods 2 to 4 . In the second period, the estimated error variance is 95.62\% which is explained by the GDP itself. Other variables that have the greatest influence on GDP as a policy variable other than GDP itself INF is $3.52 \%$ then FDI is $0.79 \%$ and $N X$ is $0.035 \%$ while GE is $0.028 \%$. In the following period the influence of the independent variable on GDP fluctuated. In the medium term in the twenty-first period, the estimated error variance is $77.34 \%$ which is explained by GDP itself. The other variable that most affected GDP as a policy variable besides GDP itself was NX of $14.52 \%$, then INF of $6.74 \%$ and FDI of $0.99 \%$ while GE was $0.38 \%$. In the long run in the 60 th period, the estimated error variance is $77.26 \%$ which is explained by GDP itself. The other variable that most affected GDP as a policy variable besides GDP itself was NX of $14.60 \%$, then INF of $6.74 \%$ and FDI of $0.99 \%$ while GE was $0.38 \%$.

\section{CONCLUSIONS AND RECOMMENDATIONS}

\section{Conclusion}

This study examines the analysis of factors that affect economic growth in Indonesia. Based on the results of the research that has been done, the following conclusions are obtained:

1. Based on the results of the cointegration test carried out, it can be seen that the calculated Trace Statistic and the maximum Eigenvalue is greater than the critical value, so there is cointegration at the $5 \%$ level. Trace Statistic values and maximum eigenvalues are greater than the critical value, which means that there is a long-term relationship between proven variables.

2. Based on the results of the Impulse Response Function test, it shows that in the short term there is shock in the FDI, INF, NX and GE variables, it can be seen that the responses given tend to fluctuate but in the early period FDI gave a positive

$$
\text { QE Journal | Vol.08 - No.01 - } 46
$$


response to economic growth. INF and NX, the existence of Shock, gave a positive response to economic growth, while the GE variable gave a negative response to economic growth.

3. Based on the results of the Impulse Response Function test, it shows that in the medium term the shock given to the FDI, INF, and NX variables gives a negative response to economic growth while the GE variable gives a positive response to economic growth even though in the next period the responses are given respectively variables tend to fluctuate.

4. Based on the results of the Impulse Response Function test, it shows that in the long run the variables FDI, INF, NX, and GE tend to fluctuate even though in the early period it was seen that the shocks given to the FDI, INF, and NX variables gave a positive response to economic growth while the variables GE gives a negative response to economic growth.

5. Based on the results of the Variant Decomposition test, the variables FDI, INF, $\mathrm{NX}$ and GE in the short term each contributed to economic growth in Indonesia, in the first period FDI, INF, NX, and GE did not respond at all, where the variable response was appears in the second period with the greatest contribution given by the INF variable. In the medium term, the NX variable provides the greatest contribution to economic growth. In the long run, the variable that gives the biggest contribution to economic growth is the INF variable.

\section{Suggestion}

As for the suggestions that can be given related to the research results, it is still necessary to review this research using a different approach method, as well as a different review concept so that comparative studies can be carried out and support new findings.

\section{REFERENCES}

Ajija, Shochrul R., Sari Dyah W., Setianto Rahmat H., Primanti, Martha R.-Cara Cerdas Menguasai EViews", Penerbit Salemba Empat, Jakarta, 2011.

Ahmad Ma'ruf dan Latri Wihastuti. 2008. Pertumbuhan Ekonomi Indonesia : Determinan dan Prosfeknya. Jurnal Ekonomi dan Studi Pembangunan Vol-9, no-1 Arpil 2008 : 44-45.

Andriani, Prima. 2008. Analisis Pengaruh Neraca Perdagangan dan Capital Inflow terhadap Pertumbuhan Ekonomi di Indonesia, Skripsi tidak diterbitkan, Fakultas Ekonomi dan Manajemen, IPBs

Amalia, Lia. “Ekonomi Pembangunan”. Graha IImu, Yogyakarta, 2007.

Andre J. and I. Hernando, (1997). Does Inflation harm Economic Growth ? Evidance for the OECD, Banco de Espana. Working Paper 9706.

Anisa, Aulia. 2003. Analisis Pengaruh Ekspor neto, Inflasi, PMA dan PMDN terhadap Pertumbuhan Ekonomi di Indonesia periode 2000-2012. 
Antoni. 2012. Kointegrasi Antara Inflasi dan Pertumbuhan Ekonomi di Indonesia. Jurnal Ekonomi Bisnis dan Koperasi, 12(2).

Anwar. Khairil Raharjo Adisasmita dan Nursini. 2015. Ananlisis Determinan Pertumbuhan Ekonomi dan Kebutuhan Investor Kabupaten Maros.

Bank Indonesia. "Laporan Perekonomian Indonesia Tahunan”. Berbagai Edisi, Publikasi Bank Indonesia. Jakarta

Badan Pusat Statistik. "Laporan Perekonomian Indonesia “. Berbagai Edisi, Publikasi Badan Pusat Statistik. Jakarta

Badan Pusat Statistik. "Ringkasan APBN". Publikasi Badan Pusat Statistik. Jakarta

Behname, 14. "Foreign Direct Investment and Economic, Growt Evidence from Southren Asia, Athlantic Review of Economics". 2st Volume - 2012.

Boediono. (1999). Teori Pertumbuhan Ekonomi. Yogyakarta: BPFE

Case, Karl E. Dan Fair, Ray C. "Prinsip-prinsip Ekonomi". Edisi kedelapan, Penerbit Erlangga, Jakarta. 2007.

Deliarnov, 1995. Pengantar Ekonomi Makro. Jakarta: UI-Press.

Dombush, R. and Fischer, S. (2013). Macroeconomics. Mc Graw Hill. Boston.

Ernita, Dewi, Syamsul Amar dan Efrizal Syofyan. "Analisis Pertumbuhan Ekonomi, Investasi dan Konsumsi di Indonesia". Jurnal Kajian Ekonomi, 2013.

Gbosh, A and S. Philips, (1998). Inflation, Disinflation, and Growth, IMF. Working Paper.

Gujarati, Damodar N. 2003, Basic Econometric, 4th Edition, McGraw-Hill.

Gregory, N, Mankiew. “Teori Mkro ekonomi Edisi kelima”, Jakarta, Erlangga, 2003.

Hady, Hamdy. "ekonomi Internasional : Teori dan Kebijakan Perdagangan Internasional". Penerbit Ghalia Indonesia, Jakarta, 2001.

Haris, Richard. 1995, Cointegration Analysis In Econometric Modeling, Prentice Hall.

Khan, M. S. and A. S. Senhadji, (2001). The Reshold Effects in the Relationship Between Inflastion and Growth, IMF \& Staff Papers Vol-48 No.1.

Liwan, Andrey dan Evan Lau. "Managing Growth : The role of Export, Inflation and Investment in the ASEAN Neight Countries". Munich Personal Re Pec Archive, Malaysia, 2007.

Mankiew, G Gregory. 2000. Macroeconomic Theory. 4th Edition. Worth Publisher Inc.

Mardalena, Erwin. 2009. Pengaruh Investasi Swasta dan Perdagangan Internasional terhadap Pertumbuhan Ekonomi di Sumatera Selatan. Ekonomika.

Mishkin, Federic S. 2009. Ekonomi Uang, Perbankan, dan Pasar Keuangan. Buku 2 Edisi ke-8 Terjemahan. Jakarta: Salemba Empat.

Murni, Asfia. 2006. Ekonomika Makro. Yogyakarta: Refika Aditana.

QE Journal | Vol.08 - No.01 - 48 
Prathama, Ragarja. " Pengantar llu Ekonomi (Mikroekonomi dan Makroekonomi) Edisi Ketiga”, Jakarta, Lembaga Penerbit Fakultas Ekonomi Universitas Indonesia, 2008.

Putri, Ratih Dwimbantari, 2005. Pengaruh Pengeluaran Pemerintah Daerah terhadap Pertumbuhan Ekonomi Dearah di Indonesia periode 1996-2003. Tesis, Universitas Air Langga, Surabaya.

Salvatore, D. (2007). International Ecocomics, New Jersey: Prentice-Hall.

Samoelson dan Nordhaus. 2004. IImu Makro Ekonomi. Jakarta: Media Global Edukasi.

Sarel, M. (1995). Non-Linear Effects of Inflation on Economic Growth, IMF Working Paper No.WP/95/56.

Shina, (2000). "Government Expenditure and Economic Growth in Malaysia". Journal of Economic Development.

Silvia, Engla Desnim et al. 2013. Analisis Pertumbuhan Ekonomi, Investasi dan Inflasi di Indonesia. Jurnal Kajian Ekonomi, I(02): 224-243.

Sims, C. A. 1990, Are Forecasting Models Usable For Policy Analysis, Federal Reserve Bank of Minneapolis QuarerlyReview.

Sjoberg, (2003). Government "Expenditure Effect on Economic Growth the Case of Sweden 1990 - 2001". Working Paper, World Bank.

Sukirno, Sadono. 2008. Pengantar Teori Makro Ekonomi. Jakarta: Raja Grafindo Persada.

Suryana. 2000. "Ekonomi Pembangunan Problematika dan Pendekatan". Jakarta: Salemba Empat.

Suseno dan Aisyah. 2009. Inflasi. Jakarta: Pusat Pendidikan dan Studi Kebanksentralan(PPSK). Bank Indonesia.

Todaro, Michael P, 2003, Pembangunan Ekonomi di Dunia Ketiga. Terjemahan Haris Munandar dan Puji A.L. Jakarta: Erlangga.

Vikesh Gokal and Subrina hanif, (2004). Relationshipt Betwen Inflation and Economic Growth. Economics Department, Working Paper 2004/04.

Yunan, 2009. Analisis yang mempengaruhi pertumbuhan ekonomi Indonesia. Tesis. 